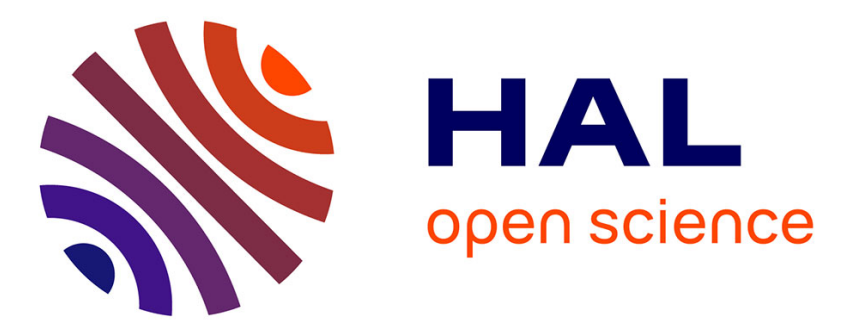

\title{
A novel, generic and effective method for the rapid purification of $\mathrm{G}$ protein-coupled receptors
}

Thierry Magnin, Cédric Fiez-Vandal, Noelle Potier-Holler, Aline Coquard, Isabelle Leray, Tania Steffan, Christel Logez, Fatima Alkhalfioui, Franc Pattus, Renaud Wagner

\section{To cite this version:}

Thierry Magnin, Cédric Fiez-Vandal, Noelle Potier-Holler, Aline Coquard, Isabelle Leray, et al.. A novel, generic and effective method for the rapid purification of $\mathrm{G}$ protein-coupled receptors. Protein Expression and Purification, 2009, 64 (1), pp.1-7. 10.1016/j.pep.2008.09.007 . hal-02979097

\section{HAL Id: hal-02979097 https://hal.science/hal-02979097}

Submitted on 26 Oct 2020

HAL is a multi-disciplinary open access archive for the deposit and dissemination of scientific research documents, whether they are published or not. The documents may come from teaching and research institutions in France or abroad, or from public or private research centers.
L'archive ouverte pluridisciplinaire HAL, est destinée au dépôt et à la diffusion de documents scientifiques de niveau recherche, publiés ou non, émanant des établissements d'enseignement et de recherche français ou étrangers, des laboratoires publics ou privés. 


\section{A R T I C L E I N F O}

Article history:

Received 5 June 2008

and in revised form 1 September 2008

Available online $\mathrm{xxxx}$

\section{Keywords:}

$\mathrm{G}$ protein-coupled receptor

Pichia pastoris

Solubilization

Purification

Cannabinoid

Opioid

Ligand

\begin{abstract}
A B S T R A C T
G protein-coupled receptors (GPCRs) constitute the largest family of membrane receptors and are of major therapeutic importance. Structure determination of G protein-coupled receptors and other applications require milligram quantities of purified receptor proteins on a regular basis. Recombinant GPCRs fused to a heterologous biotinylation domain were produced in the yeast Pichia pastoris. We describe an efficient method for their rapid purification that relies on the capture of these receptors with streptavidin immobilized on agarose beads, and their subsequent release by enzymatic digestion with TEV protease. This method has been applied to several GPCRs belonging to the class A rhodopsin subfamily, leading to high yields of purified proteins; it represents a method of choice for biochemical and biophysical studies when large quantities of purified GPCRs are needed.
\end{abstract}

(C) 2008 Elsevier Inc. All rights reserved.
Considerable research is ongoing in the area of membrane protein structure and function, and in recent years many efforts have been, in particular, focused on $G$ protein-coupled receptors (GPCRs). ${ }^{1}$ These proteins share a conserved architecture based on seven transmembrane segments; they are the key players of signal transduction and constitute the major group of drug targets for the pharmaceutical industry, with already more than half of modern drugs and almost $25 \%$ of the top 200 best-selling drugs targeting them [1]. Despite these crucial biological implications, very little is known about the detailed molecular mechanisms by which these membrane proteins recognize their extracellular stimuli and transmit the associated messages. The speed of discovery of novel GPCR-active drugs is hampered by the lack of structural information about these proteins, which is reflected by the fact that, to date, only rhodopsin, the rod-cell GPCR involved in dim light vision and the $\beta_{2}$-adrenergic receptor, which plays an important role in cardiovascular physiology, have been crystallized and their structures solved at 2.2 and $2.4 \AA$, respectively $[2,3]$.

For several protein families, including most of helical membrane proteins and in particular GPCRs, structural studies are still limited by low expression levels in heterologous systems

\footnotetext{
* Corresponding author. Fax: +33 390244829.

E-mail address: magnin@esbs.u-strasbg.fr (T. Magnin).

Abbreviations used: GPCRs, G protein-coupled receptors; SAV, streptavidin; TEV, tobacco etch virus; PBS, phosphate buffer saline; CHS, cholesteryl hemisuccinate.
}

and/or by difficulties in obtaining pure, homogeneous protein preparations [4].

During the last decade, the methylotrophic yeast Pichia pastoris has been increasingly used for heterologous GPCR expression [5-8]. This yeast is particularly suitable for these applications, combining multiple advantages: (i) the relatively low costs related to protein expression; (ii) the availability of protease deficient $P$. pastoris strains; (iii) the presence of a well-defined strong promoter (i.e. the alcohol oxidase promoter) for efficient overexpression; (iv) the eukaryotic nature of post-translational modifications that lack extensive glycosylation; ( $v$ ) the addressing of proteins to the plasma membrane due to the presence of targeting sequences and (vi) the feasibility of large-scale fermentation culturing when substantial quantities of material are needed.

We are currently using the $P$. pastoris system to express a dozen of GPCRs. Expression of these proteins has been optimized in a previous work [9], but their purification presented several problems: despite the relatively good levels of expression, GPCRs expressed in $P$. pastoris were very difficult to purify to homogeneity and in large quantities when conventional methods such as metal affinity chromatography and/or flag-agarose chromatography were used.

We have developed a rapid, generic purification procedure for GPCRs expressed in $P$. pastoris. This method relies on the presence of a C-terminal biotinylation domain in the recombinant proteins, allowing the high affinity capture of solubilized proteins on streptavidin (SAV) coupled to agarose beads. We also used the highly

1046-5928/\$ - see front matter (c) 2008 Elsevier Inc. All rights reserved. doi:10.1016/j.pep.2008.09.007 
specific tobacco etch virus (TEV) protease for the removal of both $\mathrm{N}$ - and $\mathrm{C}$-terminal tags and the concomitant release of the native protein. Scale-up of this purification protocol will allow large quantities of receptors to be purified, thus enabling three-dimensional crystallization attempts and other biophysical approaches.

\section{Materials and methods}

\section{Strains and plasmids}

Pichia pastoris strains expressing different GPCRs were obtained as previously described [9].

The plasmid for tobacco etch virus (TEV) protease overexpression in Escherichia coli was obtained from Gunter Stier (EMBL, Heidelberg).

The plasmid for streptavidin overexpression in E. coli was obtained from Prof. Arosio (University of Brescia) [10].

\section{Growth of P. pastoris and protein expression}

Cells were grown overnight in BMGY (1\% yeast extract; $1 \%$ peptone; $1.34 \%$ yeast nitrogen base; $1 \%$ glycerol; $0.00004 \%$ biotin; $100 \mathrm{mM}$ potassium phosphate $\mathrm{pH}$ 6.0). Next day, the cells were diluted in BMGY and grown to an $\mathrm{OD}_{600}$ of 10 . The culture was centrifuged and the pellet resuspended in the same volume of BMMY (1\% yeast extract; $1 \%$ peptone; $1.34 \%$ yeast nitrogen base; $0.5 \%$ methanol; $0.00004 \%$ biotin; $100 \mathrm{mM}$ potassium phosphate $\mathrm{pH}$ $6.0 ; 2.5 \%$ DMSO; $0.4 \mathrm{mg} / \mathrm{ml}$ histidine) for the induction of protein production through the AOX1 promoter. After $18 \mathrm{~h}$ at $23^{\circ} \mathrm{C}$, the cells were spun down, washed with PBS (phosphate buffer saline: $20 \mathrm{mM}$ sodium phosphate $\mathrm{pH} 7.4 ; 2 \mathrm{mM} \mathrm{KCl} ; 150 \mathrm{mM} \mathrm{NaCl}$ ) and either used immediately or frozen at $-80^{\circ} \mathrm{C}$.

The induction conditions deviate slightly from standard ones: we showed previously that for most receptors, including DMSO in the induction medium and performing the induction at $23{ }^{\circ} \mathrm{C}$ led to an increase in the ratio of active versus total receptor [9].

\section{Preparation of the cell membranes}

All procedures were performed on ice. The cells were resuspended in cold lysis buffer ( $50 \mathrm{mM}$ sodium phosphate $\mathrm{pH} 7.4$; $100 \mathrm{mM} \mathrm{NaCl}$; 5\% glycerol; 5 mM EDTA; $1 \mathrm{mM}$ PMSF). Cells were broken with glass beads $(0.5 \mathrm{~mm} ; 3 \times 20 \mathrm{~s})$, using a MP Biomedicals fast prep device. Cell debris and unbroken cells were removed by centrifugation at $5000 \mathrm{~g}$ for $10 \mathrm{~min}$ and the turbid supernatant containing cell membranes was ultracentrifuged at $150,000 \mathrm{~g}$ for $45 \mathrm{~min}$. The resulting pellets were resuspended in membrane buffer (50 mM Tris; pH 8.0; 120 mM NaCl; 10\% glycerol; 1 mM PMSF) and ultracentrifuged again. The membrane pellets were resuspended in membrane buffer, flash frozen in liquid nitrogen and stored at $-80^{\circ} \mathrm{C}$. Protein concentrations were determined by bicinchoninic acid assay (Pierce) using bovine serum albumin as standard.

\section{Western blotting and protein detection}

Chemiluminescent Western blotting detection reagents were from Pierce. Mouse monoclonal anti-Flag M2 antibody was from Sigma. Peroxidase-linked anti-mouse IgG was purchased from GE Healthcare. Alkaline phosphatase-coupled streptavidin and the corresponding substrate tablets (NBT/BCIP) were purchased from Sigma.

Proteins were separated by SDS-PAGE (10\% gel) and visualized with coomassie blue or transferred overnight at $30 \mathrm{~V}$ to a nitrocellulose membrane. The membrane was developed either with the
anti-FLAG M2 antibody or with alkaline phosphatase conjugated streptavidin.

\section{In vitro biotinylation}

Membranes $(50 \mu \mathrm{g})$ were mixed with $10 \mathrm{mM}$ ATP, $10 \mathrm{mM}$ MgOAc, $50 \mu \mathrm{M}$ biotin, $50 \mathrm{mM}$ bicine buffer ( $\mathrm{pH}$ 8.3) with or without $12,500 \mathrm{U}$ of biotin-protein ligase (BirA; Genecopoeia). The suspensions were incubated at $30^{\circ} \mathrm{C}$ for $40 \mathrm{~min}$, then submitted to SDS-PAGE and Western blotting. Biotinylated proteins were detected as described above.

\section{Solubilization}

Detergents were obtained from Anatrace except for CHAPS (Euromedex). Membranes were diluted to obtain a protein concentration of $1 \mathrm{mg} / \mathrm{ml}$ in the solubilization buffer (final concentrations: $50 \mathrm{mM}$ sodium phosphate $\mathrm{pH} 7.4 ; 10 \%$ glycerol; $400 \mathrm{mM}$ $\mathrm{NaCl}$ ). Then the detergent $n$-dodecyl $\beta$-D-maltopyranoside (DDM) was added to a final concentration of $1 \%$ and the solution was stirred at room temperature for $15 \mathrm{~min}$. After ultracentrifugation $(150,000 \mathrm{~g}, 45 \mathrm{~min})$, the supernatant was directly used for purification.

\section{Purification with streptavidin beads}

The supernatant obtained after solubilization was mixed with streptavidin-coated beads (see below) at various ratios. This preparation was kept overnight at $4{ }^{\circ} \mathrm{C}$ with orbital shaking; then the suspension was centrifuged at $1000 \mathrm{~g}$ for $5 \mathrm{~min}$, the supernatant was removed and the beads were incubated for $1 \mathrm{~h}$ at $30^{\circ} \mathrm{C}$ in solubilization buffer supplemented with $0.1 \%$ DDM and endoglycosidase (PNGase F, $1000 \mathrm{U}$ ). The beads were then sequentially washed with (i) solubilization buffer supplemented with $1 \%$ CHAPS, (ii) solubilization buffer supplemented with $0.1 \%$ DDM, (iii) solubilization buffer supplemented with $\mathrm{NaCl}$ (1.5 M final concentration) and $0.1 \%$ DDM, (iv) solubilization buffer supplemented with $1 \mathrm{M} \mathrm{NaSCN}$ and $0.1 \% \mathrm{DDM}$, (v) three times with solubilization buffer supplemented with $2 \mathrm{mM}$ DTT and $0.1 \%$ DDM (TEV buffer). All washing steps were performed at room temperature with gentle orbital shaking. Immobilized receptor were then cleaved off their tags and therefore released from the beads by addition of TEV protease $(1 \mu \mathrm{g}$ of protease for $20 \mathrm{mg}$ of starting membrane proteins) and shaking at $25^{\circ} \mathrm{C}$ for $0.5-16 \mathrm{~h}$.

Preparation of streptavidin, streptavidin-coated agarose beads (SAV beads) and TEV protease

Streptavidin was overproduced in E. coli and purified as described [10]. The protein was dialyzed against $0.1 \mathrm{M} \mathrm{NaHCO}_{3} \mathrm{pH} 8.3$ containing $0.5 \mathrm{M} \mathrm{NaCl}$ and then concentrated on a vivaspin concentrator (30 kDa cut-off). The protein $(0.8 \mathrm{mg} / \mathrm{ml}$ final concentration) was then coupled to cyanogen bromide-activated sepharose 4B (Sigma) according to the manufacturer's instructions, except that the sepharose beads were pre-hydrolyzed for $2 \mathrm{~h}$ at $\mathrm{pH} 8.3$ before adding streptavidin. The beads were kept at $4{ }^{\circ} \mathrm{C}$ in PBS supplemented with $0.02 \%$ sodium azide (four volumes of PBS/azide added to one volume of wet beads), and no decrease in the GPCR capture efficiency was noticed after 6 months of storage. In some experiments, used streptavidin beads were recycled by denaturation with $8 \mathrm{M}$ guanidine- $\mathrm{HCl}$ in $50 \mathrm{mM}$ citrate $\mathrm{pH} 3.0$ followed by renaturation with a decreasing guanidine concentration gradient. The capacity of these recycled beads to immobilize receptors was decreased by $40-60 \%$, when compared with unused beads.

TEV protease was overexpressed in E. coli BL21(DE3)pLysS (overnight induction in LB at $23{ }^{\circ} \mathrm{C}$ with $0.5 \mathrm{mM}$ IPTG) and then 
purified on an IMAC column (His Trap, GE healthcare) followed by a desalting step and a cation exchange chromatography at $\mathrm{pH} 6.1$ on a Mono S column (GE healthcare). After elution with a $0-1.0 \mathrm{M} \mathrm{NaCl}$ gradient, protease containing fractions, which eluted at $750 \mathrm{mM} \mathrm{NaCl}$, were aliquoted and stored at $-80^{\circ} \mathrm{C}$.

\section{Ligand binding experiments}

Binding assays were performed as previously described [9], using $10 \mathrm{nM}$ tritiated ligands CP55940 and rauwolscine for CNR2_HUMAN and ADA2B_HUMAN, respectively. The binding buffer used for the CNR2 receptor contained $50 \mathrm{mM}$ Tris- $\mathrm{HCl}$ $\mathrm{pH} 7.4,2.5 \mathrm{mM}$ EDTA, $5 \mathrm{mM} \mathrm{MgCl}_{2}$ and $0.5 \mathrm{mg} / \mathrm{ml}$ bovine serum albumin.

\section{MALDI-TOF mass spectrometry}

SDS-PAGE separated protein bands were excised from the gel and the proteins were digested according to the Shevchenko protocol [11]. The gel plugs were washed three times with $100 \mu \mathrm{l}$ of $25 \mathrm{mM}$ ammonium hydrogen carbonate $\left(\mathrm{NH}_{4} \mathrm{HCO}_{3}\right)$ and $100 \mu \mathrm{l}$ of acetonitrile. The cysteine residues were reduced by $50 \mu \mathrm{l}$ of $10 \mathrm{mM}$ dithiothreitol at $56^{\circ} \mathrm{C}$ and alkylated by $50 \mu \mathrm{l}$ of $55 \mathrm{mM}$ iodoacetamide. After dehydration with acetonitrile, the proteins were cleaved with $15 \mu \mathrm{l}$ of a $12.5 \mathrm{ng} / \mu \mathrm{l}$ solution of proteomics grade trypsin (Sigma) in $25 \mathrm{mM} \mathrm{NH} \mathrm{HCO}_{3}$. The digestion was performed overnight at room temperature. The resulting peptides were extracted with a $65 \%$ acetonitrile solution containing $5 \%$ acid formic and $0.05 \%$ SDS for $1 \mathrm{~h}$. MALDI-TOF mass measurements were carried out on an AutoFlex II TOF/TOF (Bruker Daltonik GmbH, Bremen, Germany) operating in positive reflectron mode. The samples were prepared by standard dried droplet preparation on stainless steel MALDI targets using $\alpha$-cyano- 4 -hydroxycinnamic acid as matrix. The samples were washed twice with $5 \%$ formic acid. External calibration of MALDI mass spectra was carried out using singly charged monoisotopic peaks of a mixture of bradykinin 1-7 $(m / z=757.400)$, human angiotensin II $(m / z=1046.542)$, human angiotensin $\mathrm{I}(\mathrm{m} / z=1296.685)$, substance $\mathrm{P}(\mathrm{m} / z=1347.735)$, bombesin $(m / z=1619.822)$, ACTH $1-17(m / z=2093.087)$ and ACTH 18-39 $(\mathrm{m} / \mathrm{z}=2465.199)$. Monoisotopic peptide masses were automatically annotated using Flexanalysis 3.0.

\section{Results}

GPCRs were overexpressed in $P$. pastoris as previously described [9]. The recombinant proteins comprise an $\mathrm{N}$-terminal $\alpha$-factor signal sequence from Saccharomyces cerevisiae followed by a Flag tag, a deca-histidine-tag, a tobacco etch virus (TEV) protease site, the GPCR open reading frame, a second TEV site and finally the Propionibacterium shermanii biotinylation domain at the C-terminus.

Our earlier purification schemes relied on the presence of the $\mathrm{N}$-terminal deca-histidine and Flag tags, but this strategy gave unsatisfactory results because of the poor specificity and efficiency of these tags. In these recombinant proteins, the C-terminal transcarboxylase biotinylation domain had been added mainly to detect the protein throughout the purification steps and to maintain its stability $[12,13]$. As an alternative to the first purification strategy, we decided to take advantage of the biotinylation domain to efficiently capture the GPCRs on SAV-agarose beads. The protein is immobilized on the beads through high affinity interaction, and can undergo subsequent washing treatment and might also be reconditioned. The final step relies on exploiting the TEV protease sites flanking the receptor to release the purified protein from the beads (Fig. 1).

\section{In vivo biotinylation of recombinant GPCRs expressed in Pichia} pastoris

A prerequisite for the development of such a purification method is that the receptors are efficiently biotinylated in vivo. Several studies conducted on membrane proteins fused with biotinylation tags and expressed in P. pastoris have shown that this yeast indeed possesses a biotin ligase (ortholog of the E. coli BirA protein) which biotinylates not only several low abundance Pichia proteins but also heterologous proteins $[14,15]$.

Thus, we first verified that the Pichia strains used in this study effectively contained a biotin ligase activity and that the level of in vivo biotinylation was sufficient to directly undertake purification on streptavidin-agarose. For this purpose, yeast cells overexpressing four different GPCRs or yeast cells transformed with an empty vector were grown in induction conditions. Then, membrane proteins were extracted, submitted to SDS-PAGE and transferred to a nitrocellulose membrane prior to the detection
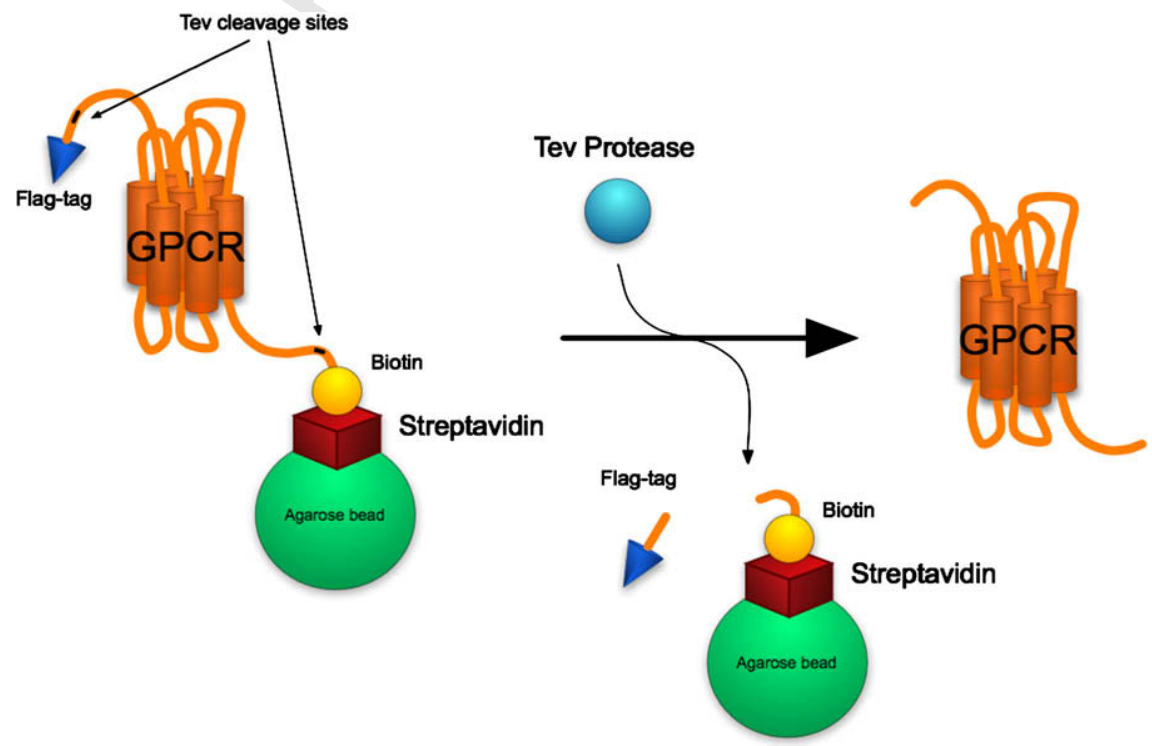

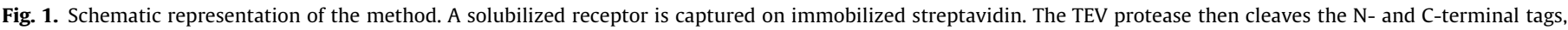
thus releasing the receptor and the $\mathrm{N}$-terminal tag. The C-terminal tag remains bound to streptavidin. 


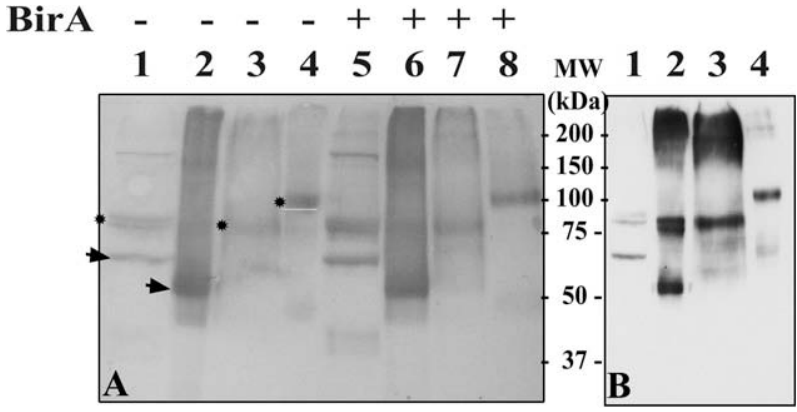

Fig. 2. Detection of four GPCRs expressed in Pichia pastoris. Membrane proteins were subjected to SDS-PAGE, and transferred to nitrocellulose. The receptors were detected with (A) Alkaline phosphatase-linked streptavidin or (B) anti-Flag M2 monoclonal antibody. Lanes 1 and 5: ADA2B_HUMAN; lanes 2 and 6: CNR2_HUMAN; lanes 3 and 7: OPRK_HUMAN; lanes 4 and 8: NK3R_HUMAN. Membranes from lanes 5 to 8 were subjected to in vitro biotinylation with the BirA proteinbiotin ligase prior to SDS-PAGE. Arrows point to receptor bands at the expected size. Asterisks show receptors for which the signal sequence was not processed, leading to molecular masses higher than expected.

of biotinylated proteins with alkaline phosphatase-linked streptavidin. For yeast transformed with an empty vector, several endogenous biotinylated proteins were detected in the soluble fractions, but none could be detected in the membrane fractions (results not shown). Fig. 2A (lanes 1-4) shows that all four receptors tested, respectively, ADA2B_HUMAN, CNR2_HUMAN, OPRK_HUMAN and NK3R_HUMAN are biotinylated in $P$. pastoris. The sizes of the detected proteins are in good agreement with those expected for ADA2B (observed Mr: $65 \mathrm{kDa}$ ) and CNR2 (55 kDa), taking into account the size contribution of the $\mathrm{N}$ - and C-terminal tags. For OPRK ( $85 \mathrm{kDa}$ ) and NK3R (100 kDa), the observed sizes are higher than expected. This is likely to be due to a lack of processing of the $\mathrm{N}$-terminal $\alpha$-factor signal sequence by internal Kex2 endopeptidase of $P$. pastoris. The same probably applies to the additional $\sim 85 \mathrm{kDa}$ doublet observed for the ADA2B receptor (Fig. 2, lanes 1 and 5). This absence of signal sequence processing was reported for the mouse $5 \mathrm{HT}_{5 \mathrm{~A}}$ receptor also expressed in P. pastoris [14].

When the membranes were treated with exogenously added biotin-protein ligase (BirA), only a slight increase in the level of biotinylation could be observed (Fig. 2A, compare lanes 1-4 and $5-8$ ), indicating that, in vivo, the biotinylation of the proteins was almost complete. Fig. 2B shows the same receptors detected with an anti-flag M2 monoclonal antibody; the bands observed are essentially the same as those detected with streptavidin-phosphatase. Taken together, these results indicate that both the $\mathrm{N}$ - and C-terminal parts of the proteins are intact since they are detected by the anti-flag antibody and streptavidin-phosphatase, respectively. Dimers and higher order oligomers are also detected, especially for CNR2 and OPRK (Fig. 2A, lanes 2, 3, 6 and 7; Fig. 2B, lanes 2 and 3). Such SDS-resistant dimers/higher order oligomers have been reported for an ever-increasing number of GPCRs [16].

These results along with the efficient in vivo biotinylation of these receptors prompted us to perform further purification tests. With the aim of developing a generic method (see Fig. 1), the human peripheral cannabinoid receptor (CNR2_HUMAN) was used as a prototypical GPCR.

CNR2_HUMAN capture onto streptavidin-coated beads and its release by TEV protease

Membrane proteins $(1 \mathrm{mg} / \mathrm{ml})$ containing CNR2_HUMAN were solubilized with $1 \%$ DDM ( $n$-dodecyl $\beta$-D-maltopyranoside) and then mixed with SAV-agarose beads. Commercial beads were tested in preliminary experiments, but the results were not as good as with our in-house made SAV beads prepared as described in
Experimental section. The difference is most likely due to the Q1 316 different levels of substitution of the agarose beads with SAV: 317 the pre-hydrolysis of the beads which we included prior to streptavidin coupling most probably leads to a lower density of SAV on the beads and thus reduces the steric hindrance problems that could be associated with a higher SAV density.

After solubilization, receptors were captured on SAV-coated beads in a batch mode. Surprisingly, very small quantities of the receptors bound to the beads within the first hours, although the streptavidin-biotin interaction is the strongest non-covalent biological interaction $\left(K_{\mathrm{a}}=10^{15} \mathrm{M}^{-1}\right)$ between a protein and its ligand known to date. The bond formation between SAV and biotin is normally rapid and essentially non-reversible, suggesting that most probably, in our case, steric hindrance due to the interaction of the biotinylated C-terminal part of the tagged GPCR with neighboring parts of the protein prevented the rapid capture of biotin by SAV. However, the quantity of bound protein increased with time, and an overnight contact at $4{ }^{\circ} \mathrm{C}$ proved to be optimum. Longer incubation times, even at higher temperatures $\left(20-37^{\circ} \mathrm{C}\right)$, did not increase the yield (data not shown). The optimal amount of home-made SAV-agarose resin necessary for the purification, starting from $20 \mathrm{mg}$ of membrane proteins, was calculated to be $1.2 \mathrm{ml}$ of resin. Increasing the resin quantity did not improve the yield of purified protein but actually slightly increased the amount of contaminants.

After capture of CNR2 on SAV, the beads were incubated in presence of an endoglycosidase (PNGase F). They were further extensively washed to remove non-specific contaminants. Several washing buffers were tested, including high and low pH buffers, high detergent and high salt buffers. The best results in terms of final receptor purity consisted in sequential washes with buffers containing (i) 1\% CHAPS for removal of contaminants interacting through hydrophobic bonds, (ii) $1.5 \mathrm{M} \mathrm{NaCl}$ for contaminants bound through hydrophilic interactions and in some cases and (iii) the chaotropic agent $\mathrm{NaSCN}(1.0 \mathrm{M})$ for very strongly bound contaminants. Then, the beads were equilibrated in TEV buffer containing $2 \mathrm{mM}$ DTT which is an essential component to maintain the functionality of the TEV protease over long periods of time. The TEV protease cleaves off the receptors from the SAV-coated beads to which the receptors are bound by their C-terminal biotinylated tag, and also releases the $\mathrm{N}$-terminal tags from the receptors. After addition of the protease, a time-course was performed to estimate the optimal incubation time: Fig. 3 shows that the cleaved receptor can be detected after $1 \mathrm{~h}$ of incubation (lane 2). Its quantity increased from 1 to $3 \mathrm{~h}$ (lanes 1-4). However, the maximum amount of receptor was obtained either after $3 \mathrm{~h}$ (lane 4 ) or after overnight incubation (lane 5). Two bands can be seen, the main one at $36 \mathrm{kDa}$ and a more hazy band at $\sim 40 \mathrm{kDa}$. Both were identified as the cannabinoid receptor by mass spectrometry (see below). The $40 \mathrm{kDa}$ band most likely represents a post-translationally modified version of the receptor.

\section{Several purified GPCRs}

The one step purification method described above was tested out on several other GPCRs belonging to the rhodopsin-related class A subfamily. Fig. 4 shows the results obtained with five of these receptors, the human neurokinin-3 receptor (NK3R_HUMAN, theoretical molecular weight $52 \mathrm{kDa}$ ), the human purinergic receptor type-1 (P2RY1_HUMAN, $42 \mathrm{kDa}$ ), the human $\kappa$-opioid receptor (OPRK_HUMAN, $43 \mathrm{kDa}$ ), the human histamine $\mathrm{H}_{1}$ receptor (HRH1_HUMAN, $56 \mathrm{kDa}$ ), the human $\alpha_{2 \mathrm{~B}}$-adrenergic receptor (ADA2B_HUMAN, $50 \mathrm{kDa}$ ). All of these receptors were obtained in a relatively pure state (Fig. 4). NK3R (lane 1) and ADA2B (lane 5) migrate at the expected molecular weights, but P2RY1 (lane 2), OPRK (lane 3) and HRH1 (lane 4) migrate slightly faster than 


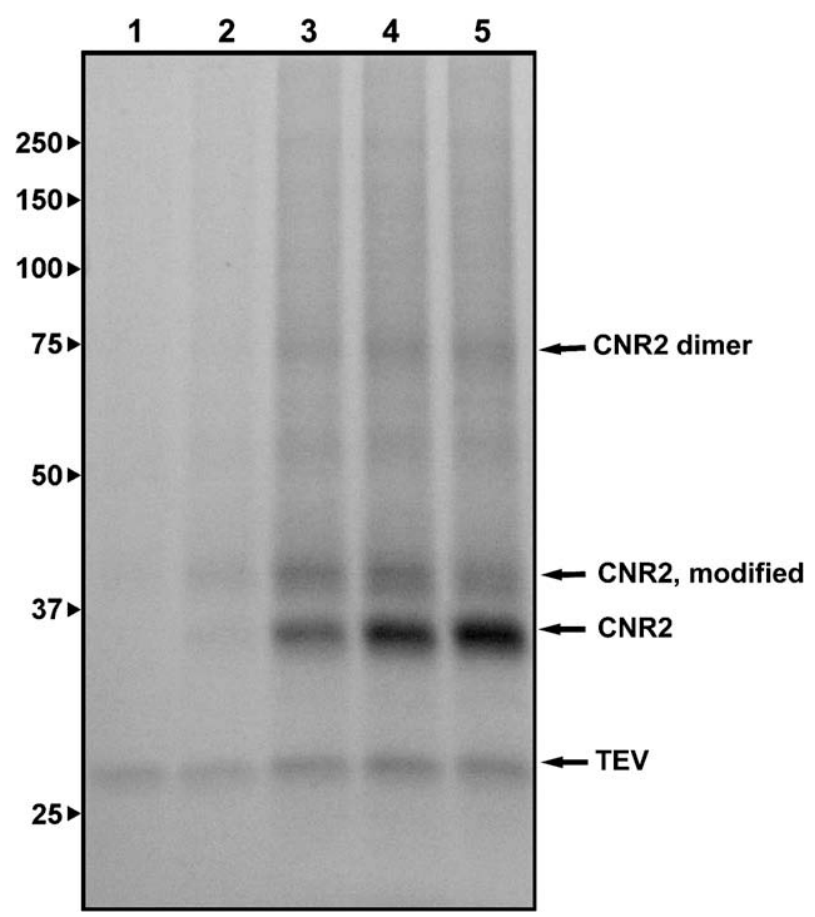

Fig. 3. Time course of CNR2 release by the TEV protease. CNR2 was solubilized and bound to streptavidin-agarose beads; the beads were washed and samples were taken at different time points after addition of the TEV protease and denatured with SDS sample buffer. Lane 1, time 0 after addition of the TEV protease; lane $2,1 \mathrm{~h}$ after addition; lane 3, 2 h; lane 4, 3 h; lane 5, 14 h (overnight).

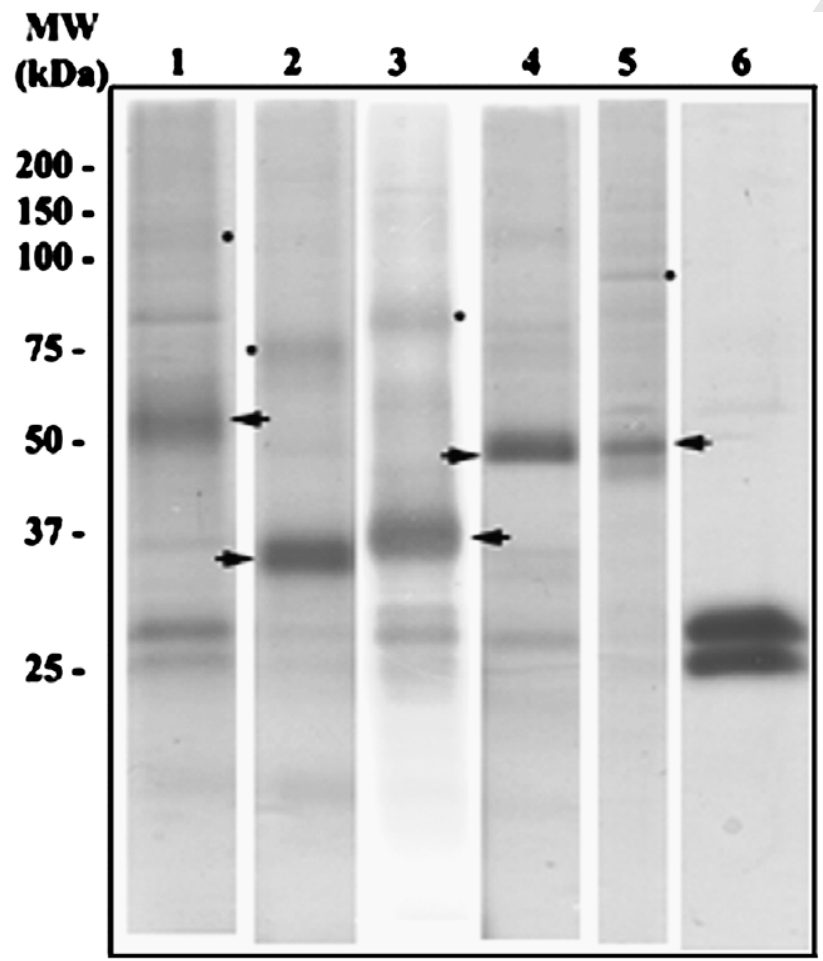

Fig. 4. Several purified GPCRs. Proteins purified with streptavidin beads were separated by SDS-PAGE and stained with coomassie blue. Lane 1, NK3R_HUMAN; lane 2, P2Y1_HUMAN; lane 3, OPRK_HUMAN; lane 4, HRH1_HUMAN; lane 5, ADA2B_HUMAN; lane 6, TEV protease. Arrowheads indicate purified GPCRs and asterisks indicate probable dimers.

expected $(34,37$ and $50 \mathrm{kDa}$, respectively). This behavior is relatively frequent with membrane proteins and particularly
Table 1

Tryptic fragments observed by MS

\begin{tabular}{lll}
\hline Receptor & Measured masses & Sequence \\
\hline OPRK & 1086.536 & $157-165$ \\
& 1176.577 & $362-371$ \\
& 1389.618 & $340-349$ \\
& 1431.763 & $360-371$ \\
CNR2 & 758.386 & $229-235$ \\
& 971.483 & $345-352$ \\
& 1045.551 & $229-237$ \\
1243.616 & $322-333$ \\
1333.612 & $307-317$ \\
& 1542.740 & $215-228$ \\
& 2075.997 & $334-352$ \\
ADA2B & 2109.026 & $14-32$ \\
& 854.459 & $58-65$ \\
& 980.569 & $23-30$ \\
& 1055.676 & $140-150$ \\
& 1186.689 & $254-264$ \\
1320.670 & $163-174$ \\
1342.804 & $254-265$ \\
1395.967 & $241-263$ \\
1722.032 & $175-191$ \\
1822.928 & $158-174$ \\
2202.289 & $117-139$ \\
2441.589 & $126-150$
\end{tabular}

Tryptic fragments were obtained and analyzed by MALDI mass spectrometry, as described in Methods section, for the following receptors: OPRK_HUMAN, CNR2_HUMAN and ADA2B_HUMAN.

among GPCRs [17]. They may bind more SDS than other proteins of similar size, due to a higher level of hydrophobicity and thus migrate faster during SDS-PAGE.

In order to confirm the identities of the purified receptors, the SDS-PAGE bands of purified OPRK, CNR2 and ADA2B, respectively, were excised and submitted to in-gel digestion followed by MALDI-TOF mass fingerprinting. As shown in Table 1, a total of 4, 8 and 11 peptides were identified for OPRK, CNR2 and ADA2B, respectively. Their masses were in concordance with the calculated molecular masses of theoretical tryptic peptides derived either from the cytoplasmic loops or from the $\mathrm{N}$ - and C-terminal domains. These analyses provided an unambiguous confirmation of the identities of the purified receptors. In the case of the CNR2 receptor, that gives two bands on SDS-PAGE (Fig. 3), both bands gave a similar pattern, thus confirming that the upper band likely represents a post-translationally modified version of the receptor.

\section{Ligand binding capacity of purified CNR2 and ADA2B receptors}

Binding assays were realized for two purified, SAV-agarose bound receptors, CNR2_HUMAN and ADA2B_HUMAN, using specific ${ }^{3} \mathrm{H}$-labelled ligands (CP 55940 and rauwolscine, respectively). Two purification conditions were tested, the first including $0.1 \%$ DDM in all buffers, the second with $0.1 \%$ DDM and $0.02 \%$ cholesteryl hemisuccinate (CHS), a well-known GPCR stabilizer. For CNR2, the binding level was $9 \mathrm{nmol} / \mathrm{mg}$ in the first condition and $10.5 \mathrm{nmol} / \mathrm{mg}$ in the second, corresponding, respectively, to $36 \%$ and $42 \%$ of active receptors in the preparation. For the ADA2B receptor, the values were much lower: 0 and $0.2 \mathrm{nmol} / \mathrm{mg}$ in the two conditions tested, respectively, corresponding to only $0 \%$ and $1 \%$ of active receptors.

\section{Yields of purification}

The yields obtained for several receptors are displayed in Table 2 . They were mainly determined by two methods. The first consisted of protein measurements made after the removal of the TEV protein and the N-terminal free tags over a gel filtration column (Superose 
Table 2

Purification yields for 10 GPCRs

\begin{tabular}{lc}
\hline Receptor & Yield $(\mathrm{mg})$ \\
\hline CNR2_HUMAN & 0.9 \\
NK1R_HUMAN & 0.05 \\
NK3R_HUMAN & 0.4 \\
ADA2B_HUMAN & 0.2 \\
ADA1B_MESAU & 0.1 \\
HRH1_HUMAN & 0.5 \\
D2DR_HUMAN & 0.05 \\
P2Y1_HUMAN & 0.5 \\
OPRD_HUMAN & 0.7 \\
OPRK_HUMAN & 0.8 \\
ADA2C_RAT & $<0.02$ \\
PAR1_HUMAN & $<0.02$ \\
\hline
\end{tabular}

The yields are expressed in $\mathrm{mg}$ of purified GPCR, obtained from $1 \mathrm{~L}$ of induced culture.

12). The second was obtained by comparing the band intensities of purified receptors on a coomassie blue stained gel with known quantities of BSA loaded on the same gels. The yields vary between 0.05 and $0.9 \mathrm{mg}$ of purified receptor per liter of culture. Since several liters of $P$. pastoris culture can be easily handled and processed, especially using the easy purification method we describe here, most of the receptors are available in sufficient quantities for biophysical studies or for other studies requiring large amounts of purified proteins. A few receptors could not be purified, e.g. the human serotonin $5 \mathrm{HT}_{1 \mathrm{~B}}$ receptor (5HT1B_HUMAN) or only purified in low amounts, e.g. the human proteinase-activated receptor 1 precursor (PAR1_HUMAN), the mesau $\alpha_{1 \mathrm{~B}}$-adrenergic receptor (ADA1B_MESAU), the human neurokinin-1 receptor (NK1R_HUMAN) and the rat $\alpha_{2 \mathrm{C}}$-adrenergic receptor (ADA2C_RAT). In addition, the human neurokinin-2 receptor (NK2R_HUMAN) could only be purified as a low molecular weight, breakdown product, due to the presence of a cryptic TEV site in its sequence, as was the case for the human neurotensin receptor [18].

\section{Discussion}

The GPCRs are the largest protein family known to date, comprised of an estimated 600-1000 members involved in various types of stimulus-response pathways, ranging from intercellular communication pathways to determination of physiological senses. GPCRs are involved in a wide range of disorders, including allergies, cardiovascular dysfunction, depression, obesity, cancer, pain, diabetes and various central nervous system disorders. The GPCR family of receptors is well-established as the premier target family for drug development: about half of the drugs on the market today are targeted towards GPCRs. Thus, taking into consideration the pharmacological importance of GPCRs, it is crucial to be able to produce pure and functional GPCRs on a custom basis to assist in the development of new GPCR targeting drugs.

Methods in use for GPCR purification from mammalian, insect, yeast or bacterial cells usually include numerous, lengthy, highcost purification steps $[4,19]$. Recent advances have been made with cell-free translational systems and the results obtained seem to be promising. However, the number of GPCRs expressed in this way is still low and the experiments are still costly and require a lot of development and optimization [20-22].

Purification methods for membrane proteins that use the avidin-biotin interaction have been developed in a few cases $[23,24]$. Usually, monomeric avidin bound to agarose has been used, but some problems, mainly concerning elution of the proteins, have been frequently reported [24]. The streptavidin-biotin is not generally used because of the very high strength of this interaction, making it virtually impossible to elute the protein of interest in mild conditions. We turned this drawback to our advantage by actually conserving the N-terminal tags in position on the streptavidin protein and exploiting TEV elution to liberate the protein of interest. The strength of the streptavidin-biotin interaction also allows, when necessary, the use of harsh washing conditions such as very high or low $\mathrm{pH}$, or high concentrations of denaturants such as urea or guanidine.

The method described here is highly efficient and allows the rapid purification of GPCRs: the purification itself can be performed within $18 \mathrm{~h}$, and only 3 days are necessary to obtain the purified protein from a starter culture. Preliminary tests can be performed, when a new GPCR or a mutated GPCR is being studied, with only $20-50 \mathrm{mg}$ of membrane proteins, thus limiting the amount of handwork needed. The costs involved are very low because of the use of the yeast $P$. pastoris, but also because no expensive purification resins or apparatuses are needed, since the method relies on the sole streptavidin-agarose resin and batch method.

The method allows easy exchange of buffers, salts and detergents, as well as addition of stabilizing additives early on in the purification process, or only at the last step involving elution by TEV. In our hands, no strong inhibition of the TEV protease could be observed, whatever the additives (specific ligands and/or CHS) or detergents used. In a previous study, the protease was shown to be inhibited by several detergents, however, the detergent concentrations used were much higher, at least by an order of magnitude, than the concentrations used in our study [25].

For most GPCRs used in this study, substantial amounts of tagfree proteins have been purified in quantities and at purity levels sufficient to initiate structural studies. Among the receptors tested, one could not be purified and a few were obtained only in low amounts. Most of these refractory receptors were nevertheless expressed and biotinylated to levels comparable to receptors purified with good yields, indicating that the problem most probably lies in the organization of the C-terminal part of the proteins, where the biotin moiety could be hindered. A possible remedy would be to add a linker between the GPCR and the biotinylation domain, thus rendering the biotin able to interact with SAV.

Besides structural studies, a possible application of the method would be to use streptavidin-agarose bound receptors to go "fishing" for receptor-interacting proteins in soluble/membrane extracts of various types of cells or tissues, in the presence or absence of added ligands. We recently obtained preliminary results showing that $\beta$-arrestin-1, a protein involved in GPCRs internalization, can be retrieved with SAV-agarose bound CNR2 receptor from an $E$. coli extract containing arrestin expressed in low amounts (results not shown). The method described here would allow (i) a direct biochemical confirmation of interactions detected by other methods such as immunoprecipitation, (ii) the identification of novel interacting partners and (iii) the possibility to release the GPCR-interacting partner complexes with the TEV protease and to realize a biochemical study of such complexes.

\section{Acknowledgments}

We are grateful to Rim Benmamaar for improving the English of the article. This study was funded by the European Membrane Protein consortium (eMeP).

\section{References}

[1] R. Fredriksson, M.C. Lagerström, L.-G. Lundin, H.B. Schiöth, The G-proteincoupled receptors in the human genome form five main families. Phylogenetic analysis, paralogon groups, and fingerprints, Mol. Pharmacol. 63 (2003) 12561272.

[2] T. Okada, M. Sugihara, A.N. Bondar, M. Elstner, P. Entel, V. Buss, The retinal conformation and its environment in rhodopsin in light of a new $2.2 \mathrm{~A}$ crystal structure, J. Mol. Biol. 342 (2004) 571-583. 
[3] V. Cherezov, D.M. Rosenbaum, M.A. Hanson, S.G. Rasmussen, F.S. Thian, T.S. Kobilka, H.J. Choi, P. Kuhn, W.I. Weiss, B.K. Kobilka, R.C. Stevens, Highresolution crystal structure of an engineered human beta\}2-adrenergic G protein coupled receptor, Science 318 (2007) 1258-1265.

[4] J.J. Lacapère, E. Pebay-Peyroula, J.-M. Neumann, C. Etchebest, Determining membrane protein structures: still a challenge!, Trends Biochem Sci. 32 (2007) 259-270.

[5] S. Noguchi, Y. Satow, Purification of human $\beta_{2}$-adrenergic receptor expressed in methylotrophic yeast Pichia pastoris, J. Biochem. 14 (2006) 799-804.

[6] H.M. Weiß, W. Haase, H. Reiländer, Expression of an integral membrane protein, in: Methods in Molecular Biology, Pichia Protocols, vol. 103, Humana press, 1998, pp 227-239.

[7] N.J. Fraser, Expression of a glycosylation deficient version of the human adenosine 2a receptor for structural studies, Protein Expr. Purif. 49 (2006) 129-137.

[8] V. Sarramegna, F. Talmont, P. Demange, A. Milon, Heterologous expression of G-protein-coupled receptors: comparison of expression systems from the standpoint of large-scale production and purification, Cell. Mol. Life Sci. 60 (2003) 1529-1546.

[9] N. André, N. Cherouati, C. Prual, T. Steffan, G. Zeder-Lutz, T. Magnin, F. Pattus, H. Michel, R. Wagner, C. Reinhart, Enhancing functional production of $G$ protein-coupled receptors in Pichia pastoris to levels required for structural studies via a single expression screen, Protein Sci. 15 (2006) 1115-1126.

[10] A. Gallizia, C. de Lalla, E. Nardone, P. Santambrogio, A. Brandazza, A. Sidoli, P. Arosio, Production of a soluble and functional recombinant streptavidin in Escherichia coli, Protein Expr. Purif. 14 (1998) 192-196.

[11] O.M. Jensen, M. Wilm, A. Shevchenko, M. Mann, Peptide sequencing of 2-DE gel-isolated proteins by nanoelectrospray tandem mass spectrometry, Methods Mol. Biol. 112 (1999) 571-588.

[12] K. Lundstrom, R. Wagner, C. Reinhart, A. Desmyter, N. Cherouati, T. Magnin, G Zeder-Lutz, M. Courtot, C. Prual, N. André, G. Hassaine, H. Michel, C. Cambillau, F. Pattus, Structural genomics on membrane proteins: comparison of more than 100 GPCRs in 3 expression systems, J. Struct. Funct. Genomics 7 (2006) 77-91.

[13] S. Grünewald, W. Haase, E. Molsberger, H. Michel, H. Reiländer, Production of the human D2S receptor in the methylotrophic yeast P. Pastoris, Receptors Channels 10 (2004) 37-50.

[14] H.M. Weiß, W. Haase, H. Michel, H. Reiländer, Comparative biochemical and pharmacological characterization of the mouse $5 \mathrm{HT}_{5 \mathrm{~A}} 5$-hydroxytryptamine receptor and the human $\beta_{2}$-adrenergic receptor produced in the methylotrophic yeast Pichia pastoris, Biochem. J. 330 (1998) 1137-1147.

[15] M. Julien, S. Kajiji, R.H. Kaback, P. Gros, Simple purification of highly active biotinylated P-glycoprotein: enantiomer-specific modulation of drugstimulated ATPase activity, Biochemistry 39 (2000) 75-85.

[16] J.A. Javitch, The ants go marching two by two: oligomeric structure of Gprotein-coupled receptors, Mol. Pharmacol. 66 (2004) 1077-1082.

[17] L. Gan, J.M. Alexander, A. Wittelsberger, B. Thomas, M. Rosenblatt, Large-scale purification and characterization of human parathyroid hormone-1 receptor stably expressed in HEK293S GnTI ${ }^{-}$cells, Protein Expr. Purif. 47 (2006) 296302.

[18] J.F. White, L.B. Trinh, J. Shiloach, R. Grisshammer, Automated large-scale purification of a $G$ protein-coupled receptor for neurotensin, FEBS Lett. 564 (2004) 289-293.

[19] V. Sarramegna, I. Muller, A. Milon, F. Talmont, Recombinant G protein-coupled receptors from expression to renaturation: a challenge towards structure, Cell. Mol. Life Sci. 63 (2006) 1149-1164.

[20] C. Klammt, A. Srivastava, N. Eifler, F. Junge, M. Beyermann, D. Schwarz, H. Michel, V. Doetsch, F. Bernhard, Functional analysis of cell-free-produced human endothelin $B$ receptor reveals transmembrane segment 1 as an essential area for ET-1 binding and homodimer formation, FEBS J. 274 (2007) 3257-3269.

[21] C. Klammt, D. Schwarz, N. Eifler, A. Engel, J. Piehler, W. Haase, S. Hahn, V. Doetsch, F. Bernhard, Reprint of "Cell-free production of G protein-coupled receptors for functional and structural studies", J. Struct. Biol. 158 (2007) 482493.

[22] G. Ishihara, M. Goto, M. Saeki, K. Ito, T. Hori, T. Kigawa, M. Shirouzu, S. Yokoyama, Expression of $G$ protein coupled receptors in a cell-free translational system using detergents and thioredoxin-fusion vectors, Protein Expr. Purif. 41 (2005) 27-37.

[23] D. Krepkiy, K. Wong, K. Gawrisch, A. Yeliseev, Bacterial expression of functional, biotinylated peripheral cannabinoid receptor CB2, Protein Expr. Purif. 49 (2006) 60-70.

[24] M. Jidenko, G. Lenoir, J.M. Fuentes, M. le Maire, C. Jaxel, Expression in yeast and purification of a membrane protein, SERCA1a, using a biotinylated acceptor domain, Protein Expr. Purif. 48 (2006) 32-42.

[25] A.K. Mohanty, C.R. Simmons, M.C. Wiener, Inhibition of tobacco etch virus protease activity by detergents, Protein Expr. Purif. 27 (2003) 109-114. 